\title{
ALASDAIR MACINTYRE: UM ARISTOTELISMO REVOLUCIONÁRIO?
}

Alasdair Macintyre: a Revolutionary Aristotelism?

Marcelo Perine *

Resumo: $\mathrm{O}$ texto pretende mostrar que o aristotelismo de MacIntyre não se deve apenas à sua original assimilação da doutrina aristotélica da virtude moral, mas está ancorado na concepção aristotélica da ação como movimento, formulada na Ética Eudêmia, cujos fundamentos ontológicos foram estabelecidos na Física e na Metafísica, bem como nos estudos de fisiologia ( $\mathrm{O}$ movimento dos animais) e de psicologia (De Anima). Alguns dos conceitos fundamentais do "Projeto Depois da Virtude" têm como fundamento a revolução na compreensão da ação moral, operada por Aristóteles em polêmica com o intelectualismo socrático e com o relativismo sofista.

Palavras-chave: MacIntyre. Neo-aristotelismo. Aristóteles. Ação moral. Virtude.

Abstract: This paper intends to show that MacIntyre's Aristotelianism not only springs from his original assimilation of the Aristotelian doctrine of moral virtue, but also that it is anchored in the Aristotelian conception of action as a movement. This conception is formulated in the Eudemian Ethics, whose ontological foundations were established in Physics and Metaphysics, as well as in physiology (The movement of animals) and psychology (De Anima). Some of the fundamental concepts of the "After Virtue Project" are based on the revolution in the understanding of moral action, operated by Aristotle in polemic with Socratic intellectualism and sophist relativism.

Keywords: MacIntyre. Neo-Aristotelianism. Aristotle. Moral Action. Virtue.

\footnotetext{
* Professor Associado da Pontifícia Universidade Católica de São Pulo (PUC-SP), doutor em Filosofia pela Pontificia Università Gregoriana (Roma), com três pós-doutorados, inclusive pela Université Lille 3 (França) em 2016-17. Artigo recebido em 24/09/2018 e aprovado para publicação em 15/10/2018.
} 


\section{O estado da arte}

S e existe alguma unanimidade em torno do polêmico filósofo escocês, que provocou "uma verdadeira avalanche nos ambientes acadêmicos de língua inglesa em 1981, com a publicação de After Virtue"1, é o fato de ser considerado "um dos principais protagonistas do movimento de reabilitação da filosofia prática desencadeado nas últimas décadas do século passado", e que "o movimento de reabilitação da Filosofia prática contemporânea, que também se nutre da crítica neo-aristotélica da modernidade e de uma consequente retomada da ética das virtudes, tem nele um dos maiores representantes" ${ }^{2}$. Esta avaliação é corroborada por Helder de Carvalho ${ }^{3}$, pioneiro dos estudos sobre MacIntyre no Brasil e, seguramente, seu interlocutor mais autorizado. Com efeito, a assim chamada "virada aristotélica" ${ }^{4}$, provocou o extraordinário crescimento do interesse pelas éticas antigas, "particularmente a de Aristóteles", constatado por Julia Annas no início dos anos $1990^{5}$, interesse que torna perfeitamente legítima a afirmação de uma "contemporaneidade de Aristóteles na filosofia moral de Alasdair MacIntyre"6.

O estado atual dos estudos macintyreanos no Brasil testemunha a relevância alcançada pelo filósofo na produção acadêmica e editorial nos últimos anos. Além dos livros de Helder de Carvalho acima citados, e de seus numerosos artigos e capítulos de livros, que se tornaram referências obrigatórias para os pesquisadores, como se verifica nas bibliografias de

\footnotetext{
${ }^{1}$ Cf. PERINE, M. Virtude, justiça, racionalidade. A propósito de Alasdair MacIntyre, Síntese Nova Fase, v. 19, n. 58 (1992) 391-412, aqui p. 391.

${ }^{2}$ Cf. ARAUjO, L. B. L. MacIntyre, Alasdair. In: BARRETO, V. de P., Dicionário de filosofia do direito, São Leopoldo/Rio de Janeiro, Editora Unisinos/Editora Renovar, 2006, p. 560-564, aqui p. 560 e p. 564, respectivamente.

${ }^{3}$ A primeira obra sistemática sobre a filosofia de MacIntyre publicada no Brasil foi a dissertação de mestrado (defendida em 1996 na UFMG) de CARVALHO, H. B. A., Tradição e racionalidade na filosofia moral de Alasdair MacIntyre, São Paulo, Unimarco Editora, 1999. A segunda edição revista foi publicada pela EDUFPI em 2011. A tese de doutorado, defendida na UFMG em 2004, também foi publicada: Hermenêutica e filosofia moral em Alasdair MacIntyre, Curitiba, Editora CRV, 2013.

${ }^{4}$ Cf. WALLACH, J. R., Contemporary Aristotelianism, Political Theory, v. 20, n. 4 (1992) 613641. Ver também: VOLPI, F. Filosofia prática. In: CANTO-SPERBER, M. (Org.), Dicionário de ética e filosofia moral, v. 1, São Leopoldo, Editora Unisinos, 2003, p. 642-649.

5 "Na última década muita atenção tem sido dada a uma opção ainda não marcada em mapas anteriores - a da assim chamada ética das virtudes. Filósofos começaram a considerar seriamente a ideia de que a moralidade pode estar, de modo muito importante, relacionada com a visão que o agente tem de sua própria vida, com a felicidade e com a virtude. E, uma vez que estas noções são centrais nas teorias antigas, houve um sério crescimento de interesse pelas teorias éticas antigas, particularmente a de Aristóteles". Cf. ANNAS, J. The Morality of Happiness. New York-Oxford, Oxford University Press, 1993, p. 4

${ }^{6}$ Cf. CARVALHO, H. B. A., A contemporaneidade de Aristóteles na filosofia moral de Alasdair MacIntyre, Síntese. Revista de Filosofia, v. 28, n. 90 (2001) 37-66.
} 
dezenas de dissertações e teses produzidas no Brasil e no exterior ${ }^{7}$, a obra de MacIntyre ganhou espaço também no calendário de eventos em nossas academias $^{8}$ e em periódicos especializados na área ${ }^{9}$. Esse estado da arte me poupa o trabalho de justificar aqui o aristotelismo ou o neo-aristotelismo de MacIntyre, inclusive porque, em sua mais recente obra ele mesmo assim define a sua posição:

Quando chamo essa posição de Neo-aristotelismo, a força do 'neo' pretende significar o seguinte. Aristóteles teve e tem comentadores e intérpretes que discordam largamente sobre como os textos relevantes devem ser entendidos. Não entrarei nessas disputas. Tomo as perspectivas que apresento como efetivamente derivadas de perspectivas de Aristóteles, porém o que mais importa são as perspectivas. Importa muito menos se elas são ou não perspectivas de Aristóteles. Ademais (...), são perspectivas para cujo desenvolvimento certos intérpretes islâmicos, judeus e cristãos de Aristóteles contribuíram notavelmente, Aquino mais do que todos. Mas se nesse ponto eu chamasse essas perspectivas de tomistas, eu me envolveria numa desnecessária controvérsia com intérpretes rivais de Aquino. Então permaneço no momento com a desconfortável etiqueta 'neo-aristotélico' ${ }^{\prime 10}$.

O título da reflexão que desenvolverei aqui foi tomado de empréstimo do quarto capítulo da obra de Kelvin Knight ${ }^{11}$. Escolhi, entretanto, acrescentar um ponto de interrogação à afirmação de Knight, não porque não esteja convencido de sua adequação, mas porque pretendo argumentar que o aristotelismo de MacIntyre é revolucionário não apenas porque, como sustenta Knight, em sua concepção de raciocínio prático "ele nunca abandonou a ideia de Marx da prática revolucionária"12, mas também porque seu conceito de virtude como prática, que assimila as dimensões cognitivas das virtudes morais sistematizadas no tratado da virtude moral

\footnotetext{
${ }^{7}$ Cf. as teses de doutorado publicadas recentemente: LINHARES, J. C. O teste histórico-dialético das tradições de pesquisa moral na filosofia de Alasdair MacIntyre, Curitiba, Editora CRV, 2014; MOTA, F. S. Da catástrofe às virtudes: a crítica de Alasdair MacIntyre ao liberalismo emotivista, São Paulo, Edições Loyola, 2014; SOUSA, J. E. As virtudes da responsabilidade compartilhada. Uma ampliação da teoria das virtudes de Alasdair MacIntyre, Curitiba, Editora CRV, 2017; GONÇALVES, Isabel C. R. H. Lei natural e natureza humana na filosofia moral de Alasdair MacIntyre, Curitiba, Editora CRV, 2018.

${ }^{8}$ A Faculdade São Luiz de Brusque promoveu uma série de três simpósios sobre a obra de MacIntyre: o primeiro sobre a ética das virtudes (2016), o segundo sobre a política (2017) e o terceiro sobre o aristotelismo/tomismo de MacIntyre (2018). O Programa de Pós-Graduação em Filosofia da UFPI organizou o I Simpósio de Filosofia Moral em 2017, cujas Atas foram publicadas por CARVALHO, Helder de. Tradição, moralidade, racionalidade. Em diálogo com Alasdair MacIntyre, Porto Alegre/Teresina, Editora Fi/EDUFPI, 2018.

${ }_{9}$ O periódico Pensando. Revista de Filosofia, do Programa de Pós-Graduação em Filosofia/ Departamento de Filosofia da UFPI publicou um Dossiê Alasdair MacIntyre no vol. 6, n. 11 de 2015, com contribuições de pesquisadores do Brasil e do exterior.

${ }^{10}$ Cf. MACINTYRE, A. Ethics in the conflicts of modernity. An Essay on Desire, Practical Reasoning, and Narrative, Cambridge, Cambridge University Press, 2016, p. 31.

${ }^{11}$ Cf. KNIGHT, K. Aristotelian Philosophy. Ethics and Politics from Aristotle to MacIntyre, Cambridge, Polity Press, 2007, cap. 4 A Revolutionary Aristotelianism, pp. 102-221.

${ }^{12}$ Id., p. 122
} 
e na concepção de phrónesis da Ética Nicomaquéia ${ }^{13}$, está profundamente ancorado na teoria aristotélica da ação voluntária, já desenvolvida na Ética Eudêmia ${ }^{14}$, cujos fundamentos devem ser buscados na Física e na Metafísica, bem como nos estudos de fisiologia e de psicologia.

\section{Um Aristóteles múltiplo?}

Extraio a interrogação do título de um artigo de Osvaldo Guariglia, que sustenta que "para reconstruir a filosofia aristotélica da ação, é necessário começar pela própria noção e pelos extenuantes esforços que o filósofo teve de realizar para torná-la independente dos filosofemas em que estava embutida"15. Segundo Guariglia, na Ética Eudêmia (II 6, 1222 b 15 - 1223 a 9), Aristóteles discute as condições necessárias para que uma ação seja moral, a saber: "1) a independência da ação de outro tipo de entidade; 2) a dependência estrita do ser humano como seu 'princípio e causa' (aspecto 'voluntário' da ação); 3) a interrelação entre o aspecto deliberativo (boúlesis) e o aspecto desiderativo (prohaíresis)".

Para Guariglia, o pano de fundo da discussão seria a teoria platônica (Filebo , 23 C - 31 A), segundo a qual há duas espécies de fenômenos: “os que possuem um caráter definido, uma medida precisa e uma completa invariabilidade, como as magnitudes numéricas, geométricas, etc., e outros que estão em constante mudança, que tanto advêm como desaparecem da existência ou variam continuamente de intensidade e graduação, de

\footnotetext{
${ }^{13} \mathrm{O}$ que ficou conhecido como "tratado da virtude moral" vai do capítulo 13 do livro I da Ética Nicomaquéia, até o capítulo 8 do livro III. A concepção aristotélica da phrónesis encontra-se no livro VI da Nicomaquéia, dedicado às virtudes intelectuais. Cf. ARISTÓTELES, Ethica Nicomachea I 3 - III 8. Tratado da virtude moral, tradução, notas e comentários de Marco Zingano, São Paulo, Odysseus Editora, 2008.

${ }^{14}$ Sobre a datação das obras éticas de Aristóteles, particularmente sobre a autenticidade da Eudêmia e sua anterioridade com relação à Nicomaquéia, ver o "Saggio Introdutivo" em: ARISTOTELE, Le tre etiche, Saggio introdutivo, traduzione, note e apparati di Arianna Fermani, Milano, Bompiani, 2008, espec. pp. XCVIII-CXVI. Para uma posição diferente, que defende a anterioridade da Ética Nicomaquéia, cf.: SCHOFIELD, M. L'Étique à Eudème: postérieure à l'Éthique à Nicomaque? Quelques preuves tirées des livres sur l'amitié, in: ROMEYER DHERBEY, G. (Dir.); AUBRY, G. (Éd.), L'excellence de la vie. Sur l'Éthique à Nicomaque et l'Éthique à Eudème d'Aristote, Paris, Vrin, 2002, pp. 299-315. Para Enrico Berti a cronologia das obras ética não é uma questão importante porque está convencido de que "Aristóteles se tenha ocupado de ética quer no início de sua atividade, isto é, no período acadêmico, quer no fim dela, isto é, durante o ensino no Liceu, sem, contudo, mudar substancialmente os seus principais pontos de vista". Cf. BERTI, E. Perfil de Aristóteles, trad. de J. Bortolini, São Paulo, Editora Paulus, 2012, p. 159.

${ }^{15}$ Cf. GUARIGLIA, O. El múltiple Aristóteles. Una visión de la filosofía práctica aristotélica desde la problemática contemporánea, Isegoría. Revista de Filosofía Moral y Política, n. 1 (1990) 85-103, aqui pp. 88 s.
} 
modo que resulta impossível evitar uma constante indeterminação, por exemplo, os precisos limites entre o calor e o frio, ou entre o úmido e o seco, etc.". Platão teria compreendido a práxis no interior do conceito de téchne, entendida como a possibilidade de aplicar relações universalmente válidas a elementos sujeitos à mudança. E dado que o corpo humano tem a mesma composição do cosmo, "a sabedoria de vida não diferirá do conhecimento científico da estrutura exata do universo" e, portanto, "o conhecimento e a norma a ele apropriada surgirão da dedução das relações matemáticas a partir dos princípios, relações que em cada caso estabelecerão o grau de verdade, de realidade e de bondade a que se pode chegar"16.

A tese de Guariglia é engenhosa, porém, a meu ver, equivocada. É certo que, na maioria das vezes, Platão é o alvo das críticas de Aristóteles. Entretanto, no que se refere à teoria da ação, o contraponto da posição aristotélica não se encontra na cosmologia e na doutrina dos quatro gêneros, que Platão expõe nas páginas do Filebo a que remete Guariglia. Para identificar os verdadeiros inimigos de Aristóteles é preciso situar sua teoria da ação no contexto histórico de Atenas nos séculos V-IV AEC, em que ocorreu o apogeu e a crise de uma cultura retórica ${ }^{17}$, no interior da qual se assistiu ao duríssimo confronto entre o revolucionário movimento sofista $^{18}$ e a Academia de Platão ${ }^{19}$.

Como afirmei em outro lugar ${ }^{20}$, o poder da retórica já era conhecido entre os gregos no tempo dos poetas mitológicos e desde então despertava controvérsias. A ninfa Peitho, literalmente, Persuasão, era considerada tanto uma divindade malévola e enganadora, como uma divindade benéfica e pacificadora, que produz concórdia por uma atração análoga à sedução erótica. Nesse sentido, pela persuasão, fundaram-se cidades, criaram-se leis e se constituiu uma vida associada; mas, por outro lado, ela é também a "tirana do gênero humano" (Écuba, 814-819), e sua arte é usada para

\footnotetext{
${ }^{16}$ Id., p. 89 s.

${ }^{17}$ Segundo D'AVENIA (L'aporia del bene apparente. Le dimensioni cognitive delle virtù morali in Aristotele, Milão, Vita e Pensiero, 1998), "pode-se definir como 'retórica' uma cultura na qual os valores que inspiram a convivência comum e a conduta moral são objeto de contínuo debate, não só porque são diversas as opiniões que se tem deles, mas sobretudo porque não é claro um critério unívoco com base no qual julgar a verdade das posições individuais" (p. 21, os grifos são do autor).

${ }^{18}$ Cf. KERFERD, G. B. O movimento sofista, trad. M. Oliva, São Paulo, Edições Loyola, 2003. Segundo Kerferd, o movimento sofista é uma das expressões culturais do "despertar do que foi chamado de autoconsciência retórica" como "característica tanto da literatura contemporânea como da discussão teórica do século V" (p. 136).

${ }^{19}$ Sobre a Academia e seu lugar na vida de Atenas, cf. BERTI, E. Symphilosophein. La vita nell'Accademia di Platone, Roma, Editori Laterza, 2010.

${ }^{20}$ Cf. PERINE, M. Persuasão, violência e diálogo, in: ID., Platão não estava doente, São Paulo, Edições Loyola, 2014, pp. 57-73, aqui p. 58.
} 
distorcer a verdade dos fatos (Medéia, 579-583) ${ }^{21}$. No âmbito dessa cultura retórica, os sofistas souberam tirar da persuasão as maiores vantagens ${ }^{22}$. O princípio protagoriano de "tornar mais forte o argumento mais fraco" ${ }^{23}$ e a tese gorgiana da palavra como "grande dominadora" ${ }^{24}$ são expressões do papel desempenhado pela sofística na difusão de uma consciência da "arte da palavra". Ademais, no substrato dessa cultura, o ideal democrático ateniense encorajou a crença de que a opinião de um homem era tão boa quanto a de qualquer outro.

Nesse ambiente cultural o axioma protagoriano do homem medida de todas as coisas $^{25}$ foi determinante para a constituição do que seria chamado posteriormente de "aporia do bem aparente". No nível do conhecimento, segundo o testemunho de Sexto Empírico, "Protágoras só admite o que aparece aos indivíduos singulares, e assim introduz o princípio da relatividade ${ }^{\prime 26}$, o que é confirmado pelo testemunho de Diógenes Laércio, segundo o qual "Protágoras foi o primeiro a dizer que em relação a qualquer assunto há duas afirmações contraditórias e argumentava dessa maneira, tendo sido o primeiro a fazê-lo" ${ }^{\prime 27}$. No nível da experiência humana sensível, decorre do axioma protagoriano que o que a um parece uma coisa, a outro parece outra, de onde procede que coisas contrárias podiam ser objeto da vontade. E dado que a arte da palavra de Górgias pretendia agir sobre as paixões a ponto de modificar as ações, o Elogio de Helena se apresentava ao ambiente cultural ateniense "não só como um exemplo e um tratado de retórica psicagógica, mas ao mesmo tempo, como o manifesto de uma ampla interpretação da ação e da moralidade humana, que revela um fundo de inevitável irracionalidade" ${ }^{\prime 28}$.

${ }^{21}$ Cf. GIANNANTONI, G. Dialogo socratico e nascita della dialettica nella filosofia di Platone. Edizione postuma a cura di Bruno Centrone, Napoli, Bibliopolis, 2005, 89 n. 1. Segundo D'Avenia, "a tragédia, lugar por excelência da educação popular, da formação dos critérios do agir pessoal e social pelas façanhas dos heróis, encontra no início do quarto século o ápice da evolução artística, que coincide também com o máximo da tensão interna, revelando a impossibilidade de encontrar um critério moral capaz de discriminar o que é justo do que não o é. A crise da tragédia apresenta aos atenienses antes de tudo a crise da racionalidade da escolha humana e as respostas que essa busca oferecer têm um notável valor heurístico, para a evolução da psicologia moral". Cf. D'AVENIA, M. L'aporia del bene apparente, op. cit., p. 36. ${ }^{22}$ Cf. UNTERSTEINER, M. A obra dos sofistas: uma interpretação filosófica, trad. R. Ambrósio, São Paulo, Editora Paulus, 2012.

${ }^{23}$ Cf. ARISTÓTELES, Retórica, 1402 a 23 [DK 80 B 6b].

${ }^{24}$ Cf. GÓRGIAS, Elogio de Helena, 8 [DK 82 B 11,8]

${ }^{25}$ Cf. SEXTO EMPÍRICO, Contra os matemáticos, VII 60 [DK 80 B 1].

${ }^{26}$ Cf. SEXTO EMPÍRICO, Esboços pirronianos I, 216 [DK A 14].

${ }^{27}$ Cf. DIÓGENES LAÉRCIO, Vidas e doutrinas dos filósofos ilustres, IX 8, 51 [DK 80 A 1].

${ }^{28}$ Cf. D'AVENIA, M. L'aporia del bene apparente, op. cit., p. 73. VEGETTI, Mario (L'etica degli antichi, Roma-Bari, Editori Laterza, 2002), sustenta que o Elogio de Helena, justamente por ser um exercício de retórica de tribunal, torna ainda mais significativo o fato de centrar-se sobre o tema da responsabilidade moral, "cujas ressonâncias parecem assim atravessar todos os ambientes da reflexão grega nesse período". Helena não pode ser considerada culpável em nenhum caso: seja que tenha fugido de Troia por decreto da Necessidade, seja que tenha sido raptada pela força, seja que tenha sido persuadida, pois "quem é persuadido pelo logos a realizar atos desventurados deve ser considerado vítima passiva, não culpável, mas apenas desafortunado" (p. 101 s.). 
Contra essa concepção se insurgiu vigorosamente a pregação de Sócrates centrada na convicção de que conhecer o bem é fazê-lo, da qual decorre a doutrina de que a virtude é ciência e o vício ignorância, com seus dois conhecidos corolários: o da irresponsabilidade do mal, ou seja, ninguém deseja o mal e os que o buscam o fazem involuntariamente, e o da negação da experiência da fraqueza do querer, isto é, da incontinência (akrasía). Daí decorrem os "paradoxos" da ética socrática, que podem ser reduzidos ao seguinte: se se pode admitir que o conhecimento do bem é condição necessária para uma vida virtuosa, não se pode admitir que seja condição suficiente. Será Platão que "descobrirá a complexa estrutura da alma humana, e mostrará que, ao lado da racionalidade, existe em nós a iracúndia e a concupiscência, e que a ação moral consiste num delicado equilíbrio dessas forças, que vê a irascibilidade (o querer) aliar-se e cooperar com a razão"29.

Sumariamente desenhado, o quadro acima identifica o problema (aporia) que a teoria aristotélica da ação deveria resolver. Reconheço que o desenho completo precisaria incluir a resposta que o Platão da maturidade deu aos paradoxos socráticos. Em favor da tese de que a descoberta platônica da complexidade da alma modificou profundamente a convicção socrática, baste a citação da seguinte passagem do Fedro:

É preciso aliás pôr em mente que em cada um de nós há duas formas de comando e de motivação, às quais seguimos por onde nos conduzam, uma que é inata, um desejo de prazeres, e a outra uma convicção adquirida, que aspira ao melhor. Essas duas formas em nós ora estão de acordo, ora em luta; e então ora é uma, ora é a outra que domina. Assim, quando uma opinião racionalmente leva ao melhor e domina, ao domínio se dá o nome de prudência (sophrosýne); mas quando o desejo irracionalmente arrasta aos prazeres e comanda em nós, eis o comando a que se deu o nome de insolência (hýbris) $(237 \mathrm{D}-238 \mathrm{~A})^{30}$.

Entretanto, a crítica mais pungente de Aristóteles à antropologia platôni$\mathrm{ca}^{31}$, na qual se fundem "a tradição pré-socrática da relação do homem com o cosmos, a tradição sofística do homem como ser de cultura (paideia),

\footnotetext{
${ }^{29}$ Cf. REALE, G. História da Filosofia Grega e Romana vol. II: Sofistas, Sócrates e socráticos menores, trad. M. Perine, São Paulo, Edições Loyola, 2009, p. 108. Sobre os paradoxos socráticos ver também: SANTAS, G. X. Socrate. La filosofia dei dialoghi giovanili di Platone, Introduzione di G. Reale, traduzione di F. Filippi, Milão, Vita e Pensiero, 2003, espec. a terceira parte "L'etica Socratica", pp. 201-335, onde defende que "o paradoxo moral não nega o fenômeno da akrasía" (p. 215).

${ }^{30}$ PLATÃO, Fedro, edição bilíngue. Tradução e apresentação de José Cavalcante de Souza. Posfácio e notas de José Trindade Santos, São Paulo, Editora 34, 2016.

${ }^{31}$ Segundo LIMA VAZ, H. C. de. (Antropologia filosófica I, São Paulo, Edições Loyola, 1993), "a antropologia platônica apresenta uma unidade que resulta da síntese dinâmica de temas, cuja oposição se concilia do ponto de vista de uma realidade transcendente à qual o homem se ordena pelo movimento profundo de todo o seu ser: a realidade das ideias. É essa ordenação transcendente que explica, no homem, a polaridade constitutiva da vida da 'alma' (psyche) na sua condição terrena" (p. 36).
} 
destinado à vida política, e a herança dominante de Sócrates do 'homem interior' e da 'alma'"'32, é, sem dúvida, a do esquecimento da experiência, que está na base do que ele chamou de "opiniões acreditadas" (tà éndoxa). Com efeito, na "passagem - segundo Berti - talvez mais famosa acerca do método da filosofia prática"33, Aristóteles afirma, na Nicomaquéia:

Ao contrário, como nos outros casos, tendo mantido firme o que se manifesta (tà phainómena) e tendo primeiro desenvolvido as aporias (diaporésantas), mostrar do modo mais exaustivo possível todas as opiniões acreditadas (tà éndoxa) expressas a respeito dessas paixões (tà páthe) ou, se isso não é possível, a maior parte delas e as mais significativas; de fato, no caso em que as dificuldades tenham sido resolvidas e as opiniões acreditadas (tà éndoxa) tenham permanecido, ter-se-á fornecido uma demonstração adequada (VII 1, 1145 b 2-7) 34 .

\section{O Aristóteles da ação e da responsabilidade}

Para Aristóteles, a desconfiança de Platão com respeito à experiência o teria levado "a descuidar esse ponto de partida contingente e a sua característica peculiar, que é a de produzir ações, seguramente conformes à verdade, mas inseridas em situações particulares". Daí procede a dupla interrogação de Aristóteles para repensar as relações entre a experiência das ações e a ciência, a saber: 1) "se é possível pensar concretamente a ciência da práxis sem uma análise fenomenológica da própria experiência da práxis e, consequentemente, sem equivocar-se sobre o estatuto da ciência moral"; 2) de que modo e se é realmente possível para o homem possuir uma ciência universal da mensuração, (...), capaz de regular infalivelmente, como basiliké téchne, toda a práxis humana" ${ }^{35}$.

A resposta aristotélica a essa dupla interrogação consistiu em "conciliar o universal e o particular, o necessário e o livre" em vista da criação de uma ciência do ethos, cujo grande problema, de acordo com Lima Vaz, "dizia respeito à descoberta de um paradigma racional segundo o qual o ethos e a praxis ética fossem explicáveis em termos universais, isto é, transcendendo a particularidade histórica das culturas e admitindo uma forma de necessidade racional compatível com a indeterminação básica da práxis" ${ }^{\prime 36}$. Para criar, nesses termos, a ciência do ethos ou a filosofia prática, Aristóteles teve de

\footnotetext{
${ }^{32}$ Cf. PERINE, M. Platão não estava doente, op. cit., p. 115.

${ }^{33}$ Cf. BERTI, E. As razões de Aristóteles, trad. de Dion D. Macedo, São Paulo, Edições Loyola, 2002, p. 133.

${ }^{34}$ Traduzido de: ARISTOTELE, Le tre etiche, op. cit.

${ }^{35}$ Cf. D'AVENIA, M. L'aporia del bene apparente, op. cit., p. 137.

${ }^{36}$ Cf. LIMA VAZ, H. C. de. Introdução à ética filosófica 1, São Paulo, Edições Loyola, 6 ${ }^{\underline{a}}$ ed., 2012, p. 60.
} 
repensar a ação humana "à luz da sua original teoria do movimento", e conjugar "de maneira não aporética a natureza com a história" ${ }^{37}$.

É na Ética Eudêmia que Aristóteles desenvolve a sua original teoria da ação voluntária, "no contexto mais amplo de uma elaboração dos conceitos de eudaimonía, como 'atividade da vida perfeita segundo a excelência perfeita' (EE II, 1, 1219 a 38) e de excelência, como 'condição que é produzida pelas melhores mudanças da alma e a partir das quais são produzidos seus melhores atos e emoções' (EE II, 1, 1220 a 29-30)"38. Aqui, a ação voluntária "não é mais o ponto de chegada de uma dedução científica da razão (segundo a tipicidade do projeto platônico), mas uma 'criação original' do homem, princípio de um movimento racionalmente qualificado no interior da variante contingente da realidade sublunar, em vista da realização da vida boa". Portanto, Aristóteles, "em explícita dialética com a tradição socrático-platônica e com o pensamento dos Sofistas, empreende a construção do sistema capaz de fundar adequadamente a ação, em nível ontológico e psicológico" ${ }^{\prime \prime 3}$.

Tendo como pano de fundo a teoria das quatro causas, formulada na Física, que define o movimento como "a atualidade do potencial enquanto tal" (he tou dynámei ontos entelécheia hei toiouton) ${ }^{40}$, juntamente com a distinção de ser em ato e ser em potência, elaborada particularmente no livro IX da Metafísica ${ }^{41}$, e a concepção da estrutura da psyché, sistematizada no De Anima, cujo ponto de partida é a definição de toda e qualquer alma como

${ }^{37}$ Cf. D'AVENIA, M. L'aporia del bene apparente, op. cit., p. 174.

${ }^{38}$ Cf. MUÑOZ, A. A. Liberdade e causalidade: ação, responsabilidade e metafísica em Aristóteles, São Paulo, Discurso Editorial/FAPESP, 2002, p. 37 s. Segundo Muñoz, "a análise da ação voluntária na Ethica eudemia surge dessa forma no contexto de um exame mais geral da excelência e do vício, produzidos no agente a partir de ações de que ele próprio é causa e princípio. Sendo o agente causa e princípio da ação (voluntária), suas ações (voluntárias) podem ser objeto de reprovação ou aprovação. Como, entretanto, elas decorrem de uma disposição do agente, é o próprio caráter como causa das ações que pode passar nesse momento a ser alvo de reprovação ou aprovação e, em seguida, as excelências e vícios que nele estão presentes. Ao ligar o conceito de ação voluntária, na Ethica eudemia, ao de ação excelente, uma análise dessa definição passa a ser exigência de um exame completo das noções de excelência e vício e do modo de sua aquisição" (p. 39). Esta obra de Muñoz é, a meu ver, o estudo mais completo da questão na recente literatura filosófica brasileira.

${ }^{39}$ Cf. D'AVENIA, M. L'aporia del bene apparente, op. cit., p. 183 e 184 respectivamente.

${ }^{40}$ Cf. ARISTÓTELES, Física, III 1, 201 a 10-11 (edição de Guillermo R. de Echandía, Madri, Editorial Gredos, 1998).

${ }^{41}$ Cf. ARISTÓTELES, Metafísica, IX, 1-9 (edição de G. Reale, São Paulo, Edições Loyola, 2014, $4^{\underline{a}}$ edição). Na impossibilidade de desenvolver mais extensamente essa questão, remeto a um estudo anterior sobre as implicações éticas da doutrina metafísica do ato e da potência: Cf. PERINE, M. Ato e potência. Implicações éticas de uma doutrina metafísica, in: ID., Quatro lições sobre a ética de Aristóteles, São Paulo, Edições Loyola, 2006, pp. 51-72. Saliento que no estudo citado tomei como referência a Ética Nicomaquéia, enquanto aqui pretendo evidenciar que a teoria aristotélica da ação foi antecipada na Eudêmia.

${ }^{42}$ Cf. ARISTÓTELES, De Anima, II, 1, 412 b 4-6 (edição de Maria C. G. dos Reis, São Paulo, Editora 34, 2012, 2ª edição). Citado DA. 
"a primeira atualidade (enteléchia) do corpo natural orgânico" ${ }^{42}$, Aristóteles formula na Ética Eudêmia a sua concepção da ação como movimento (he gar práxis kínesis, EE II, 6, 1222 b 29). Entretanto, "o movimento sozinho não esgota a experiência da práxis: é preciso que ele tenha origem num tipo de raciocínio, a deliberação, que implique o ordenamento racional ao fim e a capacidade de gerar um movimento do qual o homem seja responsável" 43 . Isso só pode ocorrer se o homem for o princípio do movimento que é a ação e se puder responder por ele, vale dizer, se o movimento/ação for o resultado de "um processo de cálculo que se estende no tempo e que será a deliberação, precedendo a escolha" ${ }^{44}$. Com efeito, se podem deliberar apenas os seres que "têm inteiramente desenvolvida a capacidade da alma que avalia a adequação de meios a fins (EE II, 10, 1226 b 25-26), é a presença, no agente, da possibilidade de ter deliberado o que determina sua responsabilidade perante uma ação e uma disposição voluntárias" ${ }^{\prime 4}$. Em coerência com a doutrina do ato e da potência de Metafísica IX (5, 1047 b 35 - 1048 a 15), ser responsável por uma ação significa ter a capacidade de agir diferentemente.

As ações humanas pelas quais se pode responder são as que entram no âmbito do hekoúsion, termo pelo qual "Aristóteles entende não tanto 'o que se realiza voluntariamente' (...), quanto 'o que procede de modo espontâneo da natureza de alguma coisa'"'46. É nesse âmbito que Aristóteles desenvolve, numa longa exposição, "sinuosa e complicada" 47 , porém inovadora na Ética Eudêmia (1223 a - 1225 b), a questão do voluntário e do involuntário, para mostrar que "os limites da conceptualização socrática e sofística consistem respectivamente em não considerar a contribuição do desejo no conhecimento prático e em não admitir a sua educabilidade por parte da razão"48. O resultado da análise mostra que, "a incontinência, quando enquadrada na dinâmica da escolha humana, é considerada por Aristóteles não como simples ignorância teorética, contraposta ao conhecimento, mas como defeito moral, vale dizer, como uma recusa consciente de assumir em primeira pessoa o peso da própria decisão" ${ }^{49}$.

\footnotetext{
${ }^{43}$ Cf. D'AVENIA, M. L'aporia del bene apparente, op. cit., p. 224 (grifos do autor). Sobre a ação voluntária na Ética Eudêmia, cf. MUÑOZ, A. A. Liberdade e causalidade, op. cit., pp. 50-86. ${ }^{44}$ Cf. MUÑOZ, A. A. Liberdade e causalidade, op. cit., p. 160. A definição do homem como "princípio de suas ações" será retomada literalmente na Nicomaquéia (1112 b 31s.). Por sua vez, a decisão (proairesis), que na Nicomaquéia é definida como um complexo de intelecto desejante (orexis nous) e desejo refletido (orexis dianoetike) (1139 b 4-5), na Eudêmia deriva de uma "opinião submetida a avalição" (dóxes bouleutikés) (1226 b 9).

${ }^{45}$ Idem, p. 177.

${ }^{46}$ Cf. D'AVENIA, M. L'aporia del bene apparente, op. cit., p. 245.

${ }^{47}$ Cf. MÉTIVIER, P. L'éthique dans le projet moral d'Aristote. Une philosophie du bien sur le modèle des arts et techniques, Paris, Les Éditions du Cerf, 2000, p. 196.

${ }^{48}$ Cf. D'AVENIA, M. L'aporia del bene apparente, op. cit., p. 253.

${ }^{49}$ Idem, p. 255.
} 
A análise da questão do voluntário e do involuntário revela que uma ação só é voluntária se satisfaz a três condições: "seu princípio está no agente, o agente podia, na ocasião, ter agido diversamente e ele estava ciente das circunstâncias e consequências de sua ação" ${ }^{20}$. É na fisiologia e na psicologia de Aristóteles que se deve buscar os fundamentos naturais da ação humana propriamente dita, que permitam responder às condições de voluntariedade e, portanto, de responsabilidade da ação humana. $\mathrm{Na}$ análise do Movimento dos animais ${ }^{51}$, por exemplo, que remete amplamente à Metafísica e à Física, Aristóteles pretende compreender "se o movimento animal, embora homogêneo às características do devir global do universo, seja independente, pelo menos em parte, do determinismo deste, e deixe espaço, no seu interior, à possibilidade de uma ação autenticamente responsável" 52 .

Aristóteles enquadra a ação dos animais como movimento e, portanto, a caracteriza por certa apreensão do fim. Afirma, a respeito:

As coisas que movem o animal são o intelecto, a sensação, a imaginação, a escolha, a vontade, o impulso e o apetite. Todos esses elementos são redutíveis ao intelecto e ao desejo. Imaginação e sensação entram na esfera do intelecto, porque se referem à faculdade de distinguir (...). Vontade, impulso, apetite entram no âmbito do desejo; a escolha, por sua vez, está entre o intelecto e o desejo. (MA VI, $700 \mathrm{~b}$ 18-23)

Em suma, intelecto e desejo são os princípios do movimento animal. Portanto, não apenas o desejo, como na perspectiva eficaz, mas desresponsabilizadora, dos Sofistas; nem tampouco apenas o intelecto, como mera colaboração defensiva do desejo: para Aristóteles o desejo é, para todos os efeitos, um princípio legítimo e imprescindível da ação humana, porque ele não considera suficiente apenas o papel da razão para produzir a ação" ${ }^{\prime \prime 3}$. Essa análise é corroborada pelo De Anima:

Mostra-se, então, que há dois fatores que fazem mover: o desejo e o intelecto, contanto que se considere a imaginação um certo pensamento. Pois muitos seguem as suas imaginações em vez da ciência, mas nos outros animais não há nem pensamento, nem raciocínio, e sim imaginação. Logo, são estes os dois capazes de fazer mover segundo o lugar: o intelecto e o desejo, mas o intelecto que raciocina em vista de algo e que é prático, o qual difere do intelecto contemplativo quanto ao fim. E todo desejo, por sua vez, é em vista de algo; pois aquilo de que há desejo é o princípio do intelecto prático, ao passo que o último termo é o princípio da ação. Assim, mostra-se razoável

\footnotetext{
${ }^{50}$ Sobre os fundamentos das ações voluntárias na psicologia e na fisiologia de Aristóteles, cf. MUÑOZ, A. A. Liberdade e causalidade, op. cit., pp. 273-324, aqui p. 273.

${ }^{51}$ Cf. ARISTOTELE, Il movimento degli animali, a cura di L. Torraca, Napoli, Libreria Scientifica Editrice, 1958 (citado $M A$ )

${ }^{52}$ Cf. D'AVENIA, M. L'aporia del bene apparente, op. cit., p. 257.

${ }^{53}$ Idem, p. 258.
} 
que sejam estes dois os que fazem mover: desejo e raciocínio prático. Pois o objeto desejável move e por isso o raciocínio também move: porque o desejável é o seu ponto de partida. (DA III, 10, 443 a 9-20) ${ }^{54}$.

Aristóteles inseriu assim o desejo na dinâmica da razão prática ${ }^{55}$. A novidade da compreensão da ação moral como movimento, na Ética Eudêmia, situa-se na continuidade da sua reflexão sobre as condições fisiológicas e psicológicas da ação, bem como dos seus fundamentos ontológicos na Metafísica e na Física. Parece-me, portanto, ter ficado evidente que "toda a estrutura da Ética Eudêmia, com a solução das aporias, se sustenta a partir do repensamento do valor do bem prático, propondo uma nova noção de 'uso' que, sem perder a referência à verdade, assume o que é exigido por ser princípio eficaz da ação no concreto" ${ }^{56}$.

\section{Um Aristóteles comunitarista? 57}

Evidentemente Aristóteles não era um comunitarista. É igualmente evidente que nem todo comunitarista é aristotélico e que nem todo aristotélico, comunitarista. Alasdair MacIntyre define a sua posição como neo-aristotélica ${ }^{58}$,

\footnotetext{
${ }^{54}$ A tradução de Maria C. G. dos Reis foi aqui ligeiramente modificada.

${ }^{55}$ Segundo Muñoz, "Quem fornece a especificidade da ação - ... - é o tipo de desejo mais forte que move o agente a praticar uma ação. Mas como a especificidade do desejo é dada pela presença ou não de uma deliberação, em última análise, embora haja ou não uma ação que seja resultado da intervenção de um desejo, haver uma ação racional ou não é resultado da associação do desejo a uma deliberação ou não". Cf. MUÑOZ, A. A. Liberdade e causalidade, op. cit., p. 281.

${ }^{56}$ Cf. D'AVENIA, M. L'aporia del bene apparente, op. cit., p. 266. A diferença entre ter conhecimento e agir conforme o conhecimento, está formulado exemplarmente no De Anima: "Além disso, mesmo que o intelecto ordene e o raciocínio diga que se evite ou busque algo, o indivíduo não se move, mas age de acordo com o apetite, como no caso dos incontinentes. Em suma, vemos que aquele que dispõe da arte de curar não cura, de modo que é algo diverso o responsável pelo agir de acordo com a ciência, e não a própria ciência" (DA, III, 9, 433 a 1-6). ${ }^{57}$ Mais uma vez empresto um título alheio para introduzir minha perspectiva. Cf. AUBENQUE, P. Aristote était-il communitariste? In: GÓMEZ, A. A.; CASTRO, R. M. (Coord.), En torno a Aristóteles. Homenaje al Professor Pierre Aubenque, Santiago de Compostela, Servicio de Publicaciones e Intercambio Científico, 1998, pp. 31-43. Aubenque discorda da interpretação macintyreana das virtudes em Aristóteles: "rien n'indique que les vertus aristotéliciennes correspondent à des modèles ou paradigmes liès à une certaine civilisation et susceptibles de varier d'une communauté à l'autre dans l'espace et dans le temps" (p. 39). Data maxima venia, tenho a impressão que Aubenque não apreendeu corretamente a posição de MacIntyre. Esta impressão é confirmada por uma citação de Justiça de quem? Qual racionalidade?, em que Aubenque, equivocamente, atribui a MacIntyre a posição relativista que ele condena (p. 40 s.). A meu ver, MacIntyre concorda com a interpretação de Aubenque de que a inspiração naturalista da filosofia de Aristóteles "ne conduit pas nécessairement au relativisme. Car la nature n'est pas seulement un donné, qui serait en effet diversifié, mais un telos, qui chez l'homme, animal raisonnable, prend la forme d'une fin à atteindre en commun, d'une tâche collective à accomplir. Cette tâche et le logos qui en est l'instrument sont les mêmes pour tous les hommes" (p. 43).
}

${ }^{58}$ Cf. supra, nota 10. 
mas recusa veementemente o rótulo de comunitarista ${ }^{59}$. Entretanto, não é o comunitarismo, mas o aristotelismo de MacIntyre que me interessa antes de suspender, mesmo sem concluir, a presente reflexão. Também não é o (neo-)aristotelismo tomista, decididamente assumido por MacIntyre a partir de Três versões rivais da investigação moral ${ }^{60}$, que será considerado aqui. Sem a menor pretensão de abranger a totalidade do assim chamado "Projeto Depois da Virtude" ${ }^{61}$, pretendo, modestamente, justificar a convicção de que o aristotelismo que está na origem do "Projeto Depois da Virtude", se não é revolucionário, é plenamente coerente com os fundamentos da filosofia prática de Aristóteles, desde a sua formulação original na Ética Eudêmia.

MacIntyre estava ciente do debate, em curso no período de elaboração de Depois da Virtude, em torno da relação da Nicomaquéia com a Eudêmia, na qual já se encontrariam as posições maduras de Aristóteles. Entretanto, afirmou que não precisava entrar nesse debate, pois a tradição na qual situava Aristóteles era "a que transformou a Ética a Nicômaco no texto canônico da teoria aristotélica das virtudes" ${ }^{62}$. A opção de MacIntyre é confirmada por grandes autoridades do aristotelismo contemporâneo, como Pierre Aubenque, que atribui à Nicomaquéia um lugar central na discussão contemporânea sobre a ética ${ }^{63}$, assim como por outras análises sobre a presença de Aristóteles nas correntes éticas contemporâneas ${ }^{64}$.

MacIntyre expressou, em Depois da virtude, a conviç̧ão de que "qualquer explicação teleológica adequada deve nos oferecer uma explicação clara e defensável do telos; e qualquer explicação adequada, de caráter aristotélico, deve oferecer uma explicação teleológica que possa substituir a biologia metafísica de Aristóteles" ${ }^{\prime 6}$. Essa convicção foi posteriormente revista e

${ }^{59}$ Cf. MACINTYRE, A. I'm not a Communitarian, Responsive Community, v. 1/3 (1991) 91-92. Também na entrevista a G. Borradori, MacIntyre nega seu pertencimento ao comunitarismo. Cf. BORRADORI, G. Filosofia americana: conversações, trad. A. Lorencini, São Paulo, Editora Unesp, 1998, p. 207. Devo essas informações a Antonio Ruzza, que defendeu recentemente uma tese de doutorado na PUCSP sob minha orientação: "A crítica de MacIntyre à modernidade: liberalismo, individualismo e teorias da justiça".

${ }^{60}$ Cf. MACINTYRE, A. Three Rival Versions of Moral Enquiry: Encyclopaedia, Genealogy, and tradition, Notre Dame, University of Notre Dame Press, 1990. Sobre isto ver: SOUSA, J. E. Alasdair MacIntyre e o tomismo: notas sobre Three Rival Versions of Moral Enquiry, Pensando. Revista de Filosofia, vol. 6, n. 11 (2015) 101-126. Sobre o tomismo de MacIntyre ver também: GONÇALVES, I. C. R. H. Lei natural e natureza humana na filosofia moral de Alasdair MacIntyre, Curitiba, Editora CRV, 2018.

${ }^{61}$ Cf. D'ANDREA, T. D. Tradition, Rationality, and Virtue: the thought of Alasdair MacIntyre, Londres/Nova Iorque, Routledge, 2017 (1 $1^{\mathrm{a}}$ ed. 2006), espec. p. 225-382.

${ }^{62}$ Cf. MACNTYRE, A. Depois da virtude, trad. de J. Simões, rev. téc. de H. B. A. de Carvalho, Bauru, Editora da Universidade do Sagrado Coração, 2001, p. 251.

${ }^{63} \mathrm{Cf}$. AUBENQUE, P. La place de l'Étique à Nicomaque dans la discussion contemporaine sur l'étique, In: ROMEYER DHERBEY, G. (Dir.); AUBRY, G. (Éd.), L'excellence de la vie. Sur l'Éthique à Nicomaque et l'Éthique à Eudème d'Aristote, Paris, Vrin, 2002, p. 397-407.

${ }^{64}$ Cf. CANTO-SPERBER, M. Aristote modernisé, In: ROMEYER DHERBEY, G. (Dir.); AUBRY, G. (Éd.), L'excellence de la vie. Sur l'Éthique à Nicomaque et l'Éthique à Eudème d'Aristote, Paris, Vrin, 2002, p. 373-395.

${ }^{65}$ Cf. MACINTYRE, A. Depois da virtude, op. cit., p. 276. 
corrigida em Animais racionais dependentes, em que MacIntyre afirma que é preciso "voltar aos textos de Aristóteles, no mínimo porque nenhum filósofo tomou mais seriamente a animalidade humana" ${ }^{66}$. Ora, essa mudança de posição a respeito da biologia metafísica de Aristóteles está na origem do que pretendi mostrar na presente reflexão, isto é, que na Ética Eudêmia, Aristóteles já teria elaborado uma teoria da ação propriamente humana, vale dizer, uma filosofia da práxis com sólidos fundamentos ontológicos na Física e na Metafísica e coerente com sua fisiologia e sua psicologia.

Entendo ser correta a afirmação de Knight de que a base da inovadora alternativa sociológica e política oferecida por MacIntyre está em sua "diferente filosofia da causação da ação" ${ }^{67}$, justamente porque, como afirma MacIntyre, "a Ética e a Política de Aristóteles (juntas, é claro, com De Anima) são tanto tratados acerca de como se deve explicar e entender a ação humana quanto acerca de quais atos realizar" ${ }^{\prime \prime 6}$. Nesse sentido, o aristotelismo revolucionário de MacIntyre, inaugurado pela releitura da doutrina aristotélica da virtude moral em Depois da virtude, já estava ancorado em uma revolução, a saber, a que foi operada por Aristóteles no debate em curso na Atenas do seu tempo a respeito do princípio (arché) da ação propriamente humana e, portanto, a respeito da possibilidade de responsabilizar o agente pela sua decisão. É o que demonstra a compreensão aristotélica da ação como movimento, tematizada na Ética Eudêmia, solidamente fundada na teoria das quatro causas da Física e na doutrina do ato e da potência da Metafísica, bem como nos estudos de fisiologia (O movimento dos animais), e de psicologia (De Anima).

Para encerrar, penso ter indicado com alguma clareza que alguns dos pilares do "Projeto Depois da Virtude", como, por exemplo, os conceitos de virtude como prática, de telos natural de uma vida humana inteira, de responsabilização da ação propriamente humana e, até mesmo, o de felicidade como atualização, isto é, florescimento ${ }^{69}$ de uma vida segundo

\footnotetext{
${ }^{66}$ Cf. MACINTYRE, A. Dependent Rational Animals: why human beings need the virtues, Chicago, Open Court, 1999, p. 5.

${ }^{67}$ Cf. KNIGHT, K. Aristotelian Philosophy, op. cit., p. 130.

${ }^{68}$ Cf. MACINTYRE, A. Depois da virtude, op. cit., p. 145 s.

${ }^{69}$ Em sua última obra MacIntyre sustenta que a concepção aristotélica de florescimento tem quatro componentes: 1) Aristóteles reconheceu o amplo leque de poderes humanos, físico, perceptivo, emocional, racional, político, moral e estético; 2) identificou como poderes tipicamente humanos os que ele (AM) identificou como decorrentes da posse da linguagem, que habilita os agentes racionais a dirigir suas atividades segundo a prescrição da razão; 3) reconheceu também aquelas habilidades humanas, cujo exercício também requer a linguagem, que permitem a associação cooperativa com outros de modos impossíveis a animais não humanos e, finalmente, 4) que nossa natureza é de tal modo que somos dirigidos por nossa formação (upbringing), se tivermos sido adequadamente educados, para fins que tomamos por bens e que temos uma concepção, ainda que inicialmente incoativa, do que seria realizar aqueles fins de modo que nossa vida seria uma vida humana perfeita, que poderia justamente ser chamada eudaimon. Cf. MACINTYRE, A. Ethics in the conflicts of modernity, op. cit., p. $28 \mathrm{~s}$.
} 
a virtude, já estavam bem assentados na formulação original da filosofia prática de Aristóteles. Se somarmos a isso a fundada convicção de Kelvin Knight, anteriormente mencionada, de que o correto entendimento da concepção de MacIntyre do conhecimento e da prática leva ao reconhecimento de que "ele nunca abandonou a ideia de Marx da prática revolucionária" ${ }^{\prime 70}$, ficará ainda mais assentado que o aristotelismo de MacIntyre é, efetivamente, revolucionário.

\section{Referências}

ANNAS, J. The Morality of Happiness. New York-Oxford, Oxford University Press, 1993.

ARAUJO, L. B. L. MacIntyre, Alasdair. In: V. de P. BARRETO, Dicionário de filosofia do direito, São Leopoldo/Rio de Janeiro, Editora Unisinos/Editora Renovar, 2006, p. $560-564$.

ARISTOTELE. Il movimento degli animali, a cura di L. Torraca, Napoli, Libreria Scientifica Editrice, 1958.

. Le tre etiche, Saggio introdutivo, traduzione, note e apparati di Arianna Fermani, Milano, Bompiani, 2008.

ARISTÓTELES. De Anima, edição de Maria C. G. dos Reis, São Paulo, Editora 34, 2012.

AUBENQUE, P. Aristote était-il communitariste? In: A. A. GÓMEZ; R. M. CASTRO (Coord.), En torno a Aristóteles. Homenaje al Professor Pierre Aubenque, Santiago de Compostela, Servicio de Publicaciones e Intercambio Científico, 1998, pp. 31-43.

La place de l'Étique à Nicomaque dans la discussion contemporaine sur l'étique, In: G. ROMEYER DHERBEY (Dir.); G. AUBRY (Éd.), L'excellence de la vie. Sur l'Éthique à Nicomaque et l'Éthique à Eudème d'Aristote, Paris, Vrin, 2002, p. 397-407.

BERTI, E. As razões de Aristóteles, trad. de Dion D. Macedo, São Paulo, Edições Loyola, 2002. terza, 2010.

Symphilosophein. La vita nell'Accademia di Platone, Roma, Editori LaPerfil de Aristóteles, trad. de J. Bortolini, São Paulo, Editora Paulus, 2012.

BORRADORI, G. Filosofia americana: conversações, trad. A. Lorencini, São Paulo, Editora Unesp, 1998.

${ }^{70}$ Cf. KNIGHT, K. Aristotelian philosophy, op. cit., p. 122. 
CANTO-SPERBER, M. Aristote modernisé, In: G. ROMEYER DHERBEY (Dir.); G. AUBRY (Éd.), L'excellence de la vie. Sur l'Éthique à Nicomaque et l'Éthique à Eudème d'Aristote, Paris, Vrin, 2002, p. 373-395.

CARVALHO, H. B. A. de. A contemporaneidade de Aristóteles na filosofia moral de Alasdair MacIntyre, Síntese. Revista de Filosofia, v. 28, n. 90 (2001) 37-66.

cIntyre, Teresina, EDUFPI, 2011.

Tradição e racionalidade na filosofia moral de Alasdair Matiba, Editora CRV, 2013.

. Hermenêutica e filosofia moral em Alasdair MacIntyre, Curi-

(Org.). Tradição, moralidade, racionalidade. Em diálogo com Alasdair MacIntyre, Porto Alegre/Teresina, Editora Fi/EDUFPI, 2018.

D'ANDREA, T. D. Tradition, Rationality, and Virtue: the thought of Alasdair MacIntyre, Londres/Nova Iorque, Routledge, 2017.

D'AVENIA, M. L'aporia del bene apparente. Le dimensioni cognitive delle virtù morali in Aristotele, Milão, Vita e Pensiero, 1998.

GIANNANTONI, G. Dialogo socratico e nascita della dialettica nella filosofia di Platone. Edizione postuma a cura di Bruno Centrone, Napoli, Bibliopolis, 2005.

GONÇALVES, I. C. R. H. Lei natural e natureza humana na filosofia moral de Alasdair MacIntyre, Curitiba, Editora CRV, 2018.

GUARIGLIA, O. El múltiple Aristóteles. Una visión de la filosofía práctica aristotélica desde la problemática contemporánea, Isegoría. Revista de Filosofía Moral y Política, n. 1 (1990) 85-103.

KERFERD, G. B. O movimento sofista, trad. M. Oliva, São Paulo, Edições Loyola, 2003.

KNIGHT, K. Aristotelian Philosophy. Ethics and Politics from Aristotle to MacIntyre, Cambridge, Polity Press, 2007.

LIMA VAZ, H. C. de. Antropologia filosófica I, São Paulo, Edições Loyola, 1993. . Introdução à ética filosófica 1, São Paulo, Edições Loyola, 6ª ed., 2012.

LINHARES, J. C. O teste histórico-dialético das tradições de pesquisa moral na filosofia de Alasdair MacIntyre, Curitiba, Editora CRV, 2014.

MACINTYRE, A. Three Rival Versions of Moral Enquiry: Encyclopaedia, Genealogy, and Tradition, Notre Dame, University of Notre Dame Press, 1990.

. I'm not a Communitarian, Responsive Community, v. 1/3 (1991) 91-92.

Chicago, Open Court, 1999.

Dependent Rational Animals: why human beings need the virtues, Depois da virtude, trad. de J. Simões, rev. téc. de H. B. A. de Carvalho, Bauru, Editora da Universidade do Sagrado Coração, 2001.

. Ethics in the conflicts of modernity. An Essay on Desire, Practical Reasoning, and Narrative, Cambridge, Cambridge University Press, 2016.

MÉTIVIER, P. L'éthique dans le projet moral d'Aristote. Une philosophie du bien sur le modèle des arts et techniques, Paris, Les Éditions du Cerf, 2000. 
MOTA, F. S. da. Da catástrofe às virtudes: a crítica de Alasdair MacIntyre ao liberalismo emotivista, São Paulo, Edições Loyola, 2014.

MUÑOZ, A. A. Liberdade e causalidade: ação, responsabilidade e metafísica em Aristóteles, São Paulo, Discurso Editorial/FAPESP, 2002.

PERINE, M. Virtude, justiça, racionalidade. A propósito de Alasdair MacIntyre, Sintese Nova Fase, v. 19, n. 58 (1992) 391-412.

. Quatro lições sobre a ética de Aristóteles, São Paulo, Edições Loyola, 2006. . Platão não estava doente, São Paulo, Edições Loyola, 2014.

PLATÃO, Fedro, edição bilíngue. Tradução e apresentação de José Cavalcante de Souza. Posfácio e notas de José Trindade Santos, São Paulo, Editora 34, 2016.

REALE, G. História da Filosofia Grega e Romana vol. II: Sofistas, Sócrates e socráticos menores, trad. M. Perine, São Paulo, Edições Loyola, 2009.

SANTAS, G. X. Socrate. La filosofia dei dialoghi giovanili di Platone, Introduzione di G. Reale, traduzione di F. Filippi, Milão, Vita e Pensiero, 2003.

SCHOFIELD, M. L'Étique à Eudème: postérieure à l'Éthique à Nicomaque? Quelques preuves tirées des livres sur l'amitié, in: G. ROMEYER DHERBEY (Dir.); G. AUBRY (Éd.), L'excellence de la vie. Sur l'Éthique à Nicomaque et l'Éthique à Eudème d'Aristote, Paris, Vrin, 2002, p. 299-315.

SOUSA, J. E. de. Alasdair MacIntyre e o tomismo: notas sobre Three Rival Versions of Moral Enquiry, Pensando. Revista de Filosofia, vol. 6, n. 11 (2015) 101-126.

- As virtudes da responsabilidade compartilhada. Uma ampliação da teoria das virtudes de Alasdair MacIntyre, Curitiba, Editora CRV, 2017.

UNTERSTEINER, M. A obra dos sofistas: uma interpretação filosófica, trad. R. Ambrósio, São Paulo, Editora Paulus, 2012.

VOLPI, F. Filosofia prática. In: M. CANTO-SPERBER (Org.), Dicionário de ética e filosofia moral, v. 1, São Leopoldo, Editora Unisinos, 2003, p. 642-649.

WALLACH, J. R. Contemporary Aristotelianism, Political Theory, v. 20, n. 4 (1992) 613-641.

Endereço do Autor

R. Itacolomi, 258 Apto. 11

01239-020 São Paulo - SP

mperine@gmail.com 